\title{
Study of factors affecting low birth weight of newborn in Uttar Pradesh, India
}

\author{
Ambri Agarwal ${ }^{1}$, Prashant Tomar ${ }^{2 *}$ \\ ${ }^{1}$ Department of Obstetrics and Gynecology, ${ }^{2}$ Department of Paediatrics, GS Medical College, Peeplabandapur,
} Pilkhuwa, Uttar Pradesh, India

Received: 15 March 2019

Accepted: 09 April 2019

*Correspondence:

Dr. Prashant Tomar,

E-mail: drtomar@gmail.com

Copyright: (C) the author(s), publisher and licensee Medip Academy. This is an open-access article distributed under the terms of the Creative Commons Attribution Non-Commercial License, which permits unrestricted non-commercial use, distribution, and reproduction in any medium, provided the original work is properly cited.

\section{ABSTRACT}

Background: Low birth weight is defined as weight at birth is less than $2.5 \mathrm{~kg}$. Low birth weight infants are at a greater risk of having a disability and survival and respiratory problems. To reduce the incidence of low birth weight babies we studied the maternal factors which affect the baby in utero and cause preterm or low birth weight babies.

Methods: Eighty-two pregnant ladies aged between 16-30 years were studied who regularly visiting to obstetrics and gynecology department of G. S. medical college hospital, Peeplabandpur, Pilkahuwa, Uttar Pradesh, India were selected for study.

Results: In this study, it was seen that mothers who were illiterate, belonging to lower socioeconomic status, multiparous and pregnancy associated with PIH, Anaemia and Oligohydramnios had high incidence of low birth weight babies.

Conclusions: This pragmatic approach study of LBW will be quite helpful to obstetrics and gynecologist, pediatrician, physician to treat such patients actively to prevent morbidity and mortality of low birth newborn which is a great threat and challenge to the medical fraternity globally.

Keywords: Ante partum hemorrhage, Low birth weight, Pregnancy induced hypertension, Premature rapture of membrane

\section{INTRODUCTION}

LBW (low birth weight) defined as weight at birth which is less than $2500 \mathrm{gm}$ usually measured in the first hour of life irrespective of the gestation age. ${ }^{1} \mathrm{LBW}$ is the major cause and contributes to about $60 \%$ to $80 \%$ of all neonatal deaths. ${ }^{2}$ Based on epidemiological studies, infants weighing less than $2500 \mathrm{gm}$, are more, likely to, die than normal weight babies. Global occurrence of LBW is $15.5 \%$ which amounts to about 20 million low birth weight infants each year. $96.5 \%$ of them in developing countries. ${ }^{3}$ Many of the LBW newborn become the victims of protein energy malnutrition (PEM) and infection. The causes of LBW are socio-economic status, poor nutrition during pregnancy, education level, and awareness of health condition. LBW is one of the most serious challenges for mother and child health. It has number of public health consequences such as mental retardation, congenital anomalies, morbidity and mortality. Moreover, very high cost of special care and intensive care unit. ${ }^{4}$ Hence attempt was made to study the different causes of LBW because there is increase of neonatal death every year globally.

\section{METHODS}

Eighty two pregnant ladies aged between 16-30 years, regularly visiting to obstetrics and gynecology department of G. S. Medical College Hospital, 
Peeplabandpur, Pilkahuwa, Uttar Pradesh, were selected for study.

The maternal history was- qualification, 38 (46.3\%) were illiterate, $28(34 \%)$ were primary school educated, 16 $(19.5 \%)$ were secondary school educated. The habits were, $4(4.87 \%)$ were smokers, $36(43.9 \%)$ were passive smokers, $42(51.2 \%)$ were Tobacco chewers. Socioeconomic status was $12(14.6 \%)$ were house wives, 17 (20.7) were shop keepers, 53 (64.3\%) were laborer. The material age was, $38(46.3 \%)$ were aged between $16-19$ were, $29(35.3 \%)$, were aged between $20-25,15(18.2 \%)$ were aged between 26-30. The clinical manifestation during pregnancy was-14 (17\%) had PIH, 4 (4.87\%) had pre-eclampsia, $2(2.43 \%)$ had eclampsia, $6(7.31 \%)$ had gestational diabetes, 24 (29.2\%) had APH, 32 (30\%) had PROM. The obstetric factors were $30(36.5 \%)$ were prim pares, $52(63.4 \%)$ were multiparous, 62 (75.6\%) had history of LBW, 38 (46.3\%) had history of miscarriage, the period of amenorrhea was-22 $(26.8 \%)$ had 28 to 37 weeks, $53(64.3 \%)$ had $38-40$ weeks $7(8.53 \%)$ had above 40 week $5(6.09 \%)$ had multiple pregnancy.

The duration of the study was about 2 years (from September-2016 to December-2018).

\section{Inclusion criteria}

- The All pregnant females attending obstretic OPD's regularly.

\section{Exclusion criteria}

- Unbooked patients

- Patients with H/O still born babies,multiple pregnancies, congenital abnormal babies

- Patients with neurological complications HIV, HBsAG+ve females.

\section{RESULTS}

- Qualification study $38(46.3 \%)$ were illiterate, 28 $(34 \%)$ were qualified up to primary school, 16 (19.5\%) up to high school (Secondary school).

- Habit study- 4 (4.87\%) were smokers, 36 (43.9\%) were passive smokers, $42(5.2 \%)$ were Tobacco chewers.

- Socio- economic status- $12(14.6 \%)$ were house wives, $17(20.7 \%)$ were shop keepers, 53 (34.3\%) laborer.

- Age of maternal was, 38 (46.3\%) were between 1619 years, $29(35.3 \%)$ were between $20-25$ years 15 (18.2\%) were aged between 26-30.

The 14 (17\%) had PIH (pregnancy induces hypertension), $4(4.87 \%)$ had Pre-eclampsia, $6(7.31 \%)$ had gestational Diabetes mellitus, 24 (29.2\%) had APH (Ante partum hemorrhage), 32 (39\%) had PROM (premature rapture of membrane).
Table 1: Maternal history in LBW fetal study.

\begin{tabular}{|lcl|}
\hline $\begin{array}{l}\text { Particulars } \\
\text { Qualification }\end{array}$ & $\begin{array}{l}\text { No. of patients } \\
\text { N=82 }\end{array}$ & $\begin{array}{l}\text { Percentage } \\
(\%)\end{array}$ \\
\hline Illiterate & 38 & 46.3 \\
\hline Primary school & 28 & 34.1 \\
\hline High school & 16 & 19.5 \\
\hline Habits & & \\
\hline Smokers & 04 & 4.87 \\
\hline Passive smokers & 36 & 43.9 \\
\hline Tobacco chewers & 42 & 51.2 \\
\hline Scio-Economic status & \\
\hline House wife & 12 & 14.6 \\
\hline Shop keepers & 17 & 20.7 \\
\hline Labors & 53 & 64.3 \\
\hline Age of the maternal & \\
\hline 16-20 years & 38 & 46.3 \\
\hline 20-25 years & 29 & 35.3 \\
\hline 26-30 years & 15 & 18.2 \\
\hline
\end{tabular}

Table 2: Study of clinical manifestation during pregnancy.

\begin{tabular}{|lll|}
\hline Particulars & $\begin{array}{l}\text { No. of } \\
\text { patients } \\
\text { N=82 }\end{array}$ & $\begin{array}{l}\text { Percentage } \\
(\%)\end{array}$ \\
\hline PIH pregnancy Induced HIN & 14 & 17 \\
\hline Pre-eclampsia & 04 & 4.87 \\
\hline Eclampsia & 02 & $2-43$ \\
\hline Gestation diabetes & 06 & 7.31 \\
\hline $\begin{array}{l}\text { APH Ante partum } \\
\text { haermarrage }\end{array}$ & 24 & 27.2 \\
\hline $\begin{array}{l}\text { PROM Premature rapture of } \\
\text { membrane }\end{array}$ & 32 & 39 \\
\hline
\end{tabular}

Table 3: Obstetric factors affecting $\mathrm{LBW}$.

\begin{tabular}{|c|c|c|}
\hline Particulars & $\begin{array}{l}\text { No. of } \\
\text { patients } \mathrm{N}=\mathbf{8 2}\end{array}$ & $\begin{array}{l}\text { Percentage } \\
(\%)\end{array}$ \\
\hline \multicolumn{3}{|l|}{ Parity } \\
\hline Primiparous & 30 & 36.5 \\
\hline Multiparious & 52 & 63.4 \\
\hline $\begin{array}{l}\text { Previous history of } \\
\text { LBW }\end{array}$ & 62 & 75.6 \\
\hline History of miscarriage & 38 & 46.3 \\
\hline \multicolumn{3}{|c|}{ Period of amenorrhea at delivery } \\
\hline 28-37 week & 22 & 26.8 \\
\hline $38-40$ week & 53 & 64.6 \\
\hline Above 40 week & 07 & 8.53 \\
\hline Multiple pregnancy & 05 & 6.09 \\
\hline
\end{tabular}

The $30(36.5 \%)$ were primiparous, $52(63.4 \%)$ were multiparous, $62(75.6 \%)$ had previous history of LBW, $38(46.3 \%)$ had history of miscarriage. The period of amenorrhea at delivery, $22(26.8 \%)$ had $28-37$, weeks, 53 
$(64.6 \%)$ had $38-40$ weeks, $7(8.53 \%)$ had above 40 weeks, 5 (6.09\%) had multiple pregnancies.

\section{DISCUSSION}

In the present study of factors, affecting LBW of newborn in Uttar Pradesh. The maternal history was qualification $38(46.3 \%)$ were illiterate, $28(34 \%)$ were studied till primary school. $16(19.5 \%)$ were educated till secondary school. The habits were $4(4.8 \%)$ were smoker, $36(43.9 \%)$ were passive smokers, $42(51.2 \%)$ were Tobacco chewer (like Gutaka). The Socio-economic status was 12 (14.6\%) were house wife, 17 (20.7\%) were shop keepers, $53(64.3 \%)$ were laborer. The age of pregnant mothers was $38(46.3 \%)$ were between 16-19 years, $29(35.3 \%)$ were aged between $20-25,15(18.2 \%)$ were 26-30 years old (Table 1). The clinical manifestation of pregnant mother was $14(17 \%) \mathrm{PIH}$ (Pregnancy induced hypertension HTN), 4 (4.87\%) had pre-eclampsia, $2(2.43 \%)$ had eclampsia, $6(7.3 \%)$ had gestational diabetes 24 (29-2\%) APH (Ante partum hemorrhage), 32 (39\%) had PROM (Premature Rupture of Membrane) (Table 2). The obstetric factors were - In parity study $30(36.5 \%)$ were primparous, $52(63.4 \%)$ were multiparous, $62(75.6 \%)$ mothers had previous history of LBW, 38 (46.3\%) mother had history of miscarriage. The period of amenorrhea was $22(26.8 \%)$ had 28-37 weeks, $53(64.6 \%)$ had $38-40$ weeks, 7 $(8.53 \%)$, had above 40 weeks, $5(6 \%)$ mothers had multiple pregnancies. This finding were more or less in agreement with previous studies. ${ }^{5-7}$

The socio- economic conditions such as poverty, education level, violence during pregnancy, passive smoking (because her husband or father in law, family members could be smokers) early marriages are also contributing factors for LBW. Infectious agents have potential to penetrate through uterus in lesser immunity females and cause inflammation in uterus and placenta. Cytokines are released in response to the inflammation by the body immune system resulting in preterm initiation of labor which results in LBW. ${ }^{8}$ Adolescent when become pregnant before their own growth is completed faces difficulty in fulfilling their own and nutritional requirement. It has been also reported that passive smokers exposure to beedi or cigarettes smoking contains a complex mixture of various mutagenic which endogenous to growing fetus. ${ }^{9}$

LBW individuals experience much health complication throughout their life which can cause long and short terms consequences including hypothermia, perinatal asphyxia respiratory problems, hyperbilirubinemia, anemia, infection, neurological problems. Ophthalmic complications, hearing defects, sudden infant death syndrome, coronary artery disease, immune-system problems. ${ }^{10}$ LBW could be due to serious placental problems leading to insufficient transport of nutrient and oxygen to fetus. Hence expecting mother must have proper nutritional intake and regular medical check-up moreover expecting mothers should not take selfmedicine without advice of physician or obstetrics and gynecologist.

Sometimes premature LBW babies need to be born to save mothers life due to other complications like anomalies of placenta, severe bleeding etc. It is also hypothesized that, violence during pregnancy leads to stress and strain on growing fetus may impair or retard the growth of fetus lead to LBW with de-arrangements of cardio-vascular and central nervous system. The LBW babies suffer with this de-arrangement in their future life, such children will be burden to whole family and society as well.

During pregnancy, apart from proper nutrition, regular medical check-up, expecting mothers should be treated, sympathetically and amicably for healthy growth of fetus.

\section{CONCLUSION}

The present study of factors affecting LBW of newborn in Uttar Pradesh will be quite useful to obstetric and gynecologist, physician pediatrician to avoid the morbidity and mortality of newborn. It is necessary improve the maternal health through nutrition and education because maternal malnutrition and anemia have significant association with LBW but this study further demands genetic, immunological, nutritional and embryological study because exact function of placental barrier and duration of formation of germ layers is still un-clear.

\section{Funding: No funding sources Conflict of interest: None declared \\ Ethical approval: The study was approved by the Institutional Ethics Committee}

\section{REFERENCES}

1. WHO report; Maternal newborn child and adolescent health care of per term and or low birth weight newborn 2013. Available at: http;www. Who, int/maternal, child adolescent/topics/newborn/care of preterm/en.

2. Zeleke B, Zalalem M, Mohammed N. Study of low birth babies pan. African Med J. 2012;4:32-6.

3. WHO, Guide lines on optional feeding of low birthweight infants in low and middle income ISBN; 9789241548366. 2011:60.

4. Felkey, Enguoseassie F. Maternal age parity and gestation age, parity and gestation age, on size of newborn in addis ababa East. Africa Med Journal. 1999;76(8);468-47.

5. Muthyya S. Maternal nutrition and low birth weight. $\mathrm{n}$. What is important? Ind J Med Res MN. 2009; 130:600-8.

6. Choudary AK, Chanchary A, Tiwari SC, Dwivedi. Factors associated low birth weight - among 
newborns in urban slum community in Bhopal. Ind J Pub Health. 2013;57:21-3.

7. Thome PS, Borle AL. Maternal risk factors determining birth weight of newborn A Ferlian care hospital based study. Int J Recent Trends Sci Tech. 2012;5:3-8.

8. Melville JM, Moss TJ. The immune consequences of preterm birth. Front Neurosci. 2013 May 21;7:79. doi: 10.3389/fnins.2013.00079. PubMed PMID: 23734091; PubMed Central PMCID: PMC3659282.

9. Williams DS, Sandler AB. The epidemiology of lung cancer. Cancer Treats Res. 2001;105:31-52.
10. Dafoneca C, Strufaldi. Low birth weight- neonatal study. Bio Med Central Res Notes. 2012;31(2):98102.

Cite this article as: Agarwal A, Tomar P. Study of factors affecting low birth weight of newborn in Uttar Pradesh, India. Int J Reprod Contracept Obstet Gynecol 2019;8:2087-90. 